\title{
Intuitionistic Fuzzy Real-Options Theory and its Application to Solar Energy Investment Projects
}

\author{
Huseyin Yigit Ersen', Oktay Tas ${ }^{2}$, Cengiz Kahraman ${ }^{3}$ \\ ${ }^{1}$ Istanbul Technical University \\ Macka 34367Istanbul, Turkey \\ E-mail.ersenh@itu.edu.tr,huseyinyigitersen@gmail.com \\ ${ }^{2}$ Istanbul Technical University \\ Macka 34367Istanbul, Turkey \\ E-mail.tasokta@itu.edu.tr,oktay.tas@itu.edu.tr \\ ${ }^{3}$ Istanbul Technical University \\ Macka 34367Istanbul, Turkey \\ E-mail.kahramanc@itu.edu.tr \\ cross $^{\text {ref }}$ http://dx.doi.org/10.5755/i01.ee.29.2.19206
}

\begin{abstract}
Conventional methods used in project evaluation have a static nature, which cause decision makers to examine investment projects within a narrow scope. As an alternative, real-options theory allows decision makers to use the concepts of uncertainty and managerial flexibility, which classical methods do not deal with, in valuing investment projects. Carlsson and Fuller's fuzzy real-options theory has been a solution for situations where cash flow and cost variables used in the model cannot be expressed by using classical numbers but by using fuzzy numbers. The idea of using intuitionistic fuzzy numbers in real options theory can expand the narrow scope more effectively than the idea of using classical real-options theory, thereby providing an opportunity to evaluate investment projects from a wider perspective. In this study, intuitionistic fuzzy real-option valuation model has been developed and applied to the evaluation of solar energy investment projects. Studies have shown that solar energy investments that do not seem profitable today in Turkey can perform profitably in the future. Moreover, the historical volatility model differs from the expected valuable models, whereas the optimum investment year between the models formed by the uncertainty inductions from the expected values exhibit minimal difference.
\end{abstract}

Keywords: Real Options; Solar Energy; Intuitionistic Fuzzy Sets; Net Present Value; Investment Projects; Intuitionistic Fuzzy Real Options.

\section{Introduction}

Recently, many investment opportunities have emerged due to existing technology and market standards, and the developing technology and favorable changes in market conditions. At the realization stage of the investment projects, every investor makes decisions upon evaluating their experiences, intuitions, or feelings. At this point, the feasibility of the projects is examined based on classical methods such as net present value, internal profitability ratio, or payback period. However, market changes, uncertainties related to technological developments, and managerial flexibilities are not considered by these classical methods. In conclusion, the managers may miss good opportunities because of their limited perspective.

The theory of instrumentalization of financial options on real investment decisions due to the uncertainty notion has appeared in the literature as real options. After the option pricing model of Black \& Scholes (1973) was introduced in 1973, the term "real options" was first expressed in the work of Stewart Myers (1977). According to Leuhrmann (1998), some strategic components can create a significant learning effect and reduce the uncertainty that allows deferment of the projects and then alteration and abandonment. By applying real-options theory, Dixit and Pindyck (1995) and Amram and Kulatilaka (1999) defended modeling the uncertainty in real investment projects.

The real-options theory has two main objectives: to handle the uncertainty in cash flows and to consider the influence of managerial flexibility. Since future incomes and expenses have become difficult to estimate, the margin of error must be involved in the model. In addition, the idea must include managerial flexibility such as deferment, expansion, and abandonment of investments. The realoption approach meets these needs, and therefore reaches further than the classical approaches.

The fuzzy set theory introduced by Zadeh (1965) has been utilized in numerous studies. This ordinary fuzzy set later had many extensions, which can be classified (in chronological order) as Zadeh's (1975) type-2 fuzzy sets, Atanassov's (1983) intuitionistic fuzzy sets, Yager's (1986) fuzzy multisets, Smarandache's (1999) neutrosophic sets, Garibaldi, Musikasuwan and Ozen's nonstationary fuzzy sets (2005) and Torra's (2010) hesitant fuzzy sets. Atanassov intended to generalize the theory of Zadeh with 
his intuitionistic fuzzy logic theory. However, he stated that the membership degree function and the non-membership degree function may not fully explain the fuzzy number, and that the expression of the fuzzy number must include a non-null hesitation part in itself. Therefore, intuitionistic fuzzy sets have been widely accepted as an alternative to ordinary fuzzy sets (Shaw \& Roy, 2012).

Carlsson and Fuller (2003) used trapezoidal fuzzy numbers in real-options theory, and called their method fuzzy real-option valuation model based on which the present value of expected cash flows and expected costs cannot generally be expressed by crisp numbers. At this point, by using the concept of possibility along with the concept of uncertainty, the investment decision can be observed from a wider perspective. Estimated cash flows and costs are not expressed by exact numbers but the possibility of current numbers in the vicinity is also added to the model. The use of intuitionistic fuzzy sets in real-option theory provides a much more comprehensive and broad perspective to the concepts of uncertainty and flexibility.

The main point and novelty of this study is to develop a real-option pricing model with intuitionistic fuzzy numbers since decision makers require more comprehensive and informative models to value the projects that have a high degree of uncertainty in developing countries such as renewable energy investments including solar energy. An investment in solar energy facility construction may seem unprofitable and may be abandoned directly with the classical investment analyses. However, a flexible analysis based on intuitionistic fuzzy sets may provide a different result because these sets can consider all possibilities of the environmental conditions and decision-maker's hesitancy. Moreover, both the historical volatility and the volatility calculated from expected value of the intuitionistic fuzzy numbers will be used for the intiutionistic fuzzy real option valuation to compare two methods.

The rest of the article is structured as follows. In Section 2, the definition of real options and the literature review of fuzzy sets in real options are given. In Section 3, intuitionistic fuzzy sets are defined and their arithmetic operations are presented. The intuitionistic fuzzy real options model, the main topic of Section 4, and the variables used in the model are explained. In Section 5, the explanatory example is given and the study is completed with the conclusion section.

\section{Literature Review}

A real option for an investment project enables the decision maker to defer, reduce, expand, or abandon the investment project, the cost of which corresponds to strike price in financial options, for a predetermined period of time and at the cost of the option for that period (Copeland \& Antikarov, 2001). This option is called a dynamic investment valuation process. Trigeorgis (1993), who discussed the real-option theory into a book, stated the importance of managerial flexibility for investment decisions. Option to defer, option to abandon, staged investment, option to alter operating scale, option to switch, growth options, and multiple interacting options are the real-option types according to Trigeorgis (1996).
Carlsson and Fuller (2003) developed a fuzzy approach to real-option valuation because the present value of expected cash flows and expected costs cannot generally be expressed in a classical number. In the model proposed by Merton (1973), the dividend distribution variable was added to the model of Black \& Scholes (1973). The dividend distribution variable, which results in a certain reduction in cash flows, was modeled as an exponential function.

Theorem 1: If variables are defined as follows: $\tilde{S}_{0}$ is fuzzy present value of expected cash flows, $\tilde{X}$ is fuzzy value of expected investment costs, $T$ is remaining option time, $\sigma$ is standard deviation of fuzzy present value of expected cash flows, $r$ is risk-free interest rate, and $N(d)$ is cumulative standard normal distribution function, then:

Fuzzy Real-Option Value $=\widetilde{\mathrm{C}}=\widetilde{\mathrm{S}}_{0} \mathrm{e}^{-(\delta \mathrm{T})} \mathrm{N}\left(\mathrm{d}_{1}\right)-\widetilde{\mathrm{X}} \mathrm{e}^{-(\mathrm{rT})} \mathrm{N}\left(\mathrm{d}_{2}\right)$ $\mathrm{d}_{1}=\left[\ln \left(\mathrm{E}\left(\tilde{\mathrm{S}}_{0}\right) / \mathrm{E}(\widetilde{\mathrm{X}})\right)+\left(\mathrm{r}-\delta+\sigma^{2} / 2\right) \mathrm{T}\right] /(\sigma \sqrt{\mathrm{T}})$

$\mathrm{d}_{2}=\left[\ln \left(\mathrm{E}\left(\widetilde{\mathrm{S}}_{0}\right) / \mathrm{E}(\widetilde{\mathrm{X}})\right)+\left(\mathrm{r}-\delta-\sigma^{2} / 2\right) \mathrm{T}\right] /(\sigma \sqrt{ } \mathrm{T})=\mathrm{d}_{1}-\sigma \sqrt{ } \mathrm{T}$

Definition 2: Carlsson and Fuller [19] mentioned how to calculate fuzzy present value of the expected cash flows and fuzzy value of expected investment cost with respect to the left-right fuzzy numbers. This formulation is for the fuzzy numbers expressed in trapezoidal form as follows:

$\mathrm{E}(\tilde{\mathrm{A}})=\left(\mathrm{a}_{1}+2 \mathrm{a}_{2}+2 \mathrm{a}_{3}+\mathrm{a}_{4}\right) / 6$

Definition 3: Carlsson and Fuller (2001) defined the standard deviation variable and the formulation for the type-1 trapezoidal fuzzy numbers of the standard deviation expressed as left-right fuzzy numbers as follows:

$\sigma^{2}(\tilde{A})=\left(a_{3}-a_{2}\right)^{2} / 4+\left(\left(a_{3}-a_{2}\right)\left(a_{4}-a_{1}\right)\right) / 6+\left(a_{4}-a_{1}\right)^{2} / 24$

Based on the fuzzy present value of the expected cash flows from the preceding variance formula, the standard deviation value used in the expression of uncertainty is found in the model. After calculating the variance of this value, the standard deviation is calculated. At the latest stage, the standard deviation of the fuzzy value of net operation cash flows is standardized by dividing the net operation cash flows by the expected value as follows:

$\sigma=\sigma\left(\widetilde{\mathrm{S}}_{0}\right) / \mathrm{E}\left(\widetilde{\mathrm{S}}_{0}\right)$.

Lee and Lee (2011) used Carlsson and Fuller's model to determine the investment decision on radio frequency identification (RFID) systems. Their objective was to invest in advanced information technologies such as RFID systems, which have high risk, and to use options such as change, postponement, expansion, and abandonment. Ucal and Kahraman (2009) applied this model for similar purposes. However, it was intended to prevent the loss of information by leaving the expected values of cash flows and costs in the model for the next stages. Ho and Liao (2011) evaluated a two-step investment decision of a local biotechnology company using a fuzzy binomial model. On the other hand, Zmeskal (2010) proposed a fuzzy stochastic model for the American-type call option. Tolga (2009) used Carlsson and Fuller's fuzzy option valuation model as a criterion for multi-criteria decision-making models of the R\&D investment decision. You et al. (2012) used real options to invest in enterprise resource planning.

Heng, Chen, and Tan (2014) stated that modeling compound options by Geske (1979) and the theory by Agliardi and Agliardi (2013), which generalizes Geske's 
theorem in time-dependent volatility and interest rate, could be applied in land expropriation practice in a fuzzy environment. Meanwhile, Biancardi and Villani (2017) modeled the compound American Exchange options with a fuzzy approach in their study. They declared that this option approach, which is suitable for sequential structure of R\&D projects, could be used in a fuzzy environment. Furthermore, they used fuzzy volatility and dividend variables. Kozlova, Collan and Luukka (2016) compared the Datar-Mathews method based on Monte Carlo simulation, which is probability-based, and the fuzzypayoff method, which is possibility-based, and observed that the results are compliant with each other. Aranda, Arango and Lianos (2016) evaluated the distribution center of an Auxiliary Rail Freight Terminal project by using fuzzy logic and American call options and also in comparison with the Black-Scholes model. Dai, Sun, and Guo (2016) proposed a fuzzy real-option model based on the Black-Scholes model, where one can find the risk preferences of experts, and used it in Brownfield redevelopment valuation. Tolga, Kahraman and Demircan (2010) suggested a fuzzy real option model with trinomial lattice and apply it to value a call center project. They also compared the model to Fuzzy Black-Scholes approach.

\section{Intuitionistic Fuzzy Sets}

Atanassov (1983) suggested that the membership and non-membership functions may not fully express a fuzzy number, and that a hesitation part must be applied to account for a fuzzy number in large circumstances of uncertainty.

The $x$ real number of a universal set is also defined by the membership degree in the same set as well as the nonmembership degree. This is also the extended statement of the fuzzy number.

$\mu_{\tilde{A}} \tilde{i}^{\mathrm{i}}$ (membership degree): $\mathrm{E} \rightarrow[0,1]$.

$\mathrm{V}_{\tilde{\mathrm{A}}}^{\mathrm{i}}$ (non-membership degree): $\mathrm{E} \rightarrow[0,1]$.

Definition 4: Atanassov, who aimed to expand the classical fuzzy set theory, realized that these numbers could be developed for intense ambiguous circumstances and could be used to express more comprehensive uncertainty; thus, he added the following value of hesitation to theory:

$\pi_{\tilde{\AA}}^{i}$ (hesitation degree) $=1-\mu_{\tilde{A}} \tilde{i}^{i}-V_{\tilde{A}^{i}}^{i}$

Moreover, for every $x$ in the universal set, intuitionistic fuzzy numbers must have a definition that can be distinguished from the classical fuzzy theory:

$0<\mu_{\tilde{A}}^{i}+V_{\tilde{A}}^{i} \leq 1$

Definition 5: $\tilde{\mathrm{A}}^{\mathrm{i}}$ is a trapezoidal intuitionistic fuzzy number; the real numbers $a_{1}, a_{2}, a_{3}, a_{4}, b_{1}$, and $b_{2}$ are used as critical expressions in the formation of the membership degree function.The trapezoidal intuitionistic fuzzy number was expressed as follows by Shabani and Jamkhaneh (2014):

$$
\mu_{A}(x)=\left\{\begin{array}{l}
\frac{\mu_{A}\left(x-a_{1}\right)}{\left(a_{2}-a_{1}\right)}, a_{1} \leq x<a_{2} \\
\mu_{A}, a_{2} \leq x<a_{3} \\
\frac{\mu_{A}\left(a_{4}-x\right)}{\left(a_{4}-a_{3}\right)}, a_{3} \leq x<a_{4} \\
0, o_{h} \text { other } \\
V_{A}(x)=\left\{\begin{array}{c}
\frac{\left(a_{2}-x\left(1-V_{A}\right)-V_{A} b_{1}\right)}{\left(a_{2}-b_{1}\right)}, b_{1} \leq x<a_{2} \\
\frac{\left(x\left(1-V_{A}\right)+V_{A} b_{2}-a_{3}\right)}{\left(b_{2}-a_{3}\right)}, a_{3} \leq x<b_{2}
\end{array}, \text { other } a_{3}\right.
\end{array}\right.
$$

The intuitionistic fuzzy number $\tilde{\mathrm{A}}^{\mathrm{i}}$ is expressed as follows:

$$
\tilde{\mathrm{A}}^{\mathrm{i}}=\left(\mathrm{b}_{1}, \mathrm{a}_{1}, \mathrm{a}_{2}, \mathrm{a}_{3}, \mathrm{a}_{4}, \mathrm{~b}_{2}, \mu_{\mathrm{A}}, \mathrm{V}_{\mathrm{A}}\right) .
$$

As graphically, it is illustrated in Figure 1.

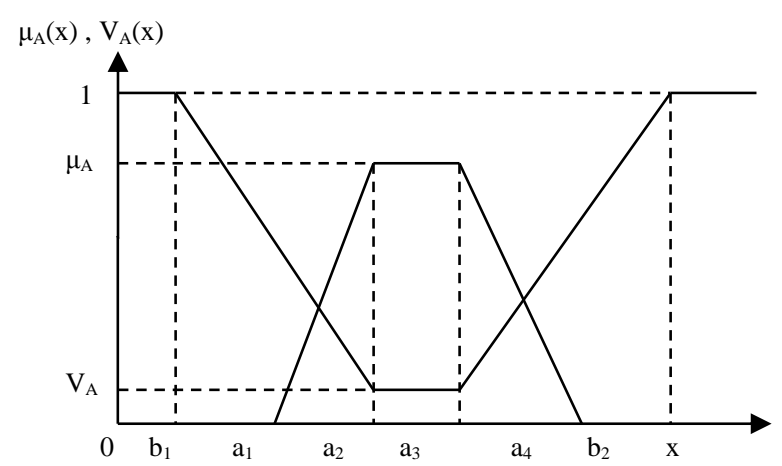

Figure 1. An Intuitionistic Fuzzy Number According to Shabani and Jamkhaneh

On the other hand, Grzegorzewski (2003) suggested a type of trapezoidal fuzzy number. As a special case, the most possible value or values of membership degree of an intuitionistic fuzzy number can be taken as 1 and the value of hesitation is set to 0 . Therefore, obscurity of the most possible value range is removed. Nehi and Maleki (2005) revealed the trapezoidal fuzzy numbers as linearly the functions of membership and non-membership degrees.

Definition 6: If an intuitionistic fuzzy number is defined as $\tilde{A}^{\mathrm{i}}=\left(\mathrm{a}_{1}, \mathrm{a}_{2}, \mathrm{a}_{3}, \mathrm{a}_{4} ; \mathrm{b}_{1}, \mathrm{a}_{2}, \mathrm{a}_{3}, \mathrm{~b}_{2}\right)$, unlike in the work of Grzegorzewski (2003) and Nehi and Maleki (2005), the most possible value range is taken to be the same in the membership and non-membership degree functions. Based on this situation, the following are the trapezoidal types of intuitionistic fuzzy numbers: 
Huseyin Yigit Ersen, Oktay Tas, Cengiz Kahraman. Intuitionistic Fuzzy Real-Options Theory and its Application to Solar...

$$
\begin{aligned}
& \mu_{A}(x)= \begin{cases}\frac{\left(x-a_{1}\right)}{\left(a_{2}-a_{1}\right)}, & a_{1} \leq x<a_{2} \\
1, & a_{2} \leq x<a_{3} \\
\frac{\left(a_{4}-x\right)}{\left(a_{4}-a_{3}\right)}, & a_{3} \leq x<a_{4} \\
0, & \text { other }\end{cases} \\
& V_{A}(x)= \begin{cases}\frac{\left(a_{2}-x\right)}{\left(a_{2}-b_{1}\right)}, & b_{1} \leq x<a_{2} \\
0, & a_{2} \leq x<a_{3} \\
\frac{\left(x_{3}\right)}{\left(b_{2}-a_{3}\right)} & , a_{3} \leq x<b_{2}\end{cases} \\
& 11, \text { other }
\end{aligned}
$$

As graphically, it is illustrated in Figure 2.

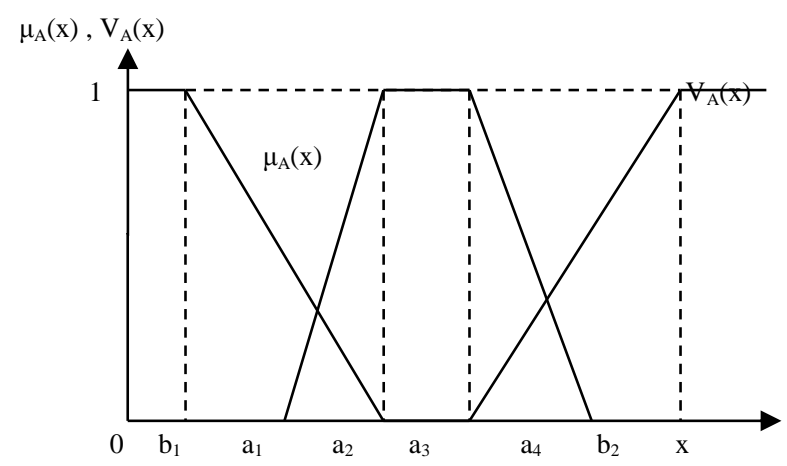

Figure 2. An Intuitionistic Fuzzy Number Whose Membership Degree of Most Possible Value Range is 1

The fuzzy number was expressed as a special case in Shabani and Jamkhaneh's theory. In this number, the membership function of the most possible value range is 1 and the non-membership function is 0. Zainali, Akbari, Noughabi (2015) used same concept in their study for L-R intuitionistic fuzzy numbers as well.

Definition 7: Operations on intuitionistic trapezoidal fuzzy numbers which are inspired by Nehi and Maleki (2005) and Kumar (2014) can be expressed as follows. $\tilde{A}^{\mathrm{i}}=$ $\left(\mathrm{a}_{1}, \mathrm{a}_{2}, \mathrm{a}_{3}, \mathrm{a}_{4} ; \mathrm{b}_{1}, \mathrm{a}_{2}, \mathrm{a}_{3}, \mathrm{~b}_{2}\right)$ and $\tilde{B}^{\mathrm{i}}=\left(\mathrm{n}_{1}, \mathrm{n}_{2}, \mathrm{n}_{3}, \mathrm{n}_{4} ; \mathrm{m}_{1}, \mathrm{n}_{2}\right.$, $\left.\mathrm{n}_{3}, \mathrm{~m}_{2}\right)$ are defined as two intuitionistic fuzzy numbers:

$\mathrm{k} \otimes \tilde{\mathrm{A}}^{\mathrm{i}}(\mathrm{k}>0) \cong\left(\mathrm{ka}_{1}, \mathrm{ka}_{2}, \mathrm{ka}_{3}, \mathrm{ka}_{4} ; \mathrm{kb}_{1}, \mathrm{ka}_{2}, \mathrm{ka}_{3}, \mathrm{~kb}_{2}\right)$

$\mathrm{k} \otimes \tilde{\mathrm{A}}^{\mathrm{i}}(\mathrm{k}<0) \cong\left(\mathrm{ka}_{4}, \mathrm{ka}_{3}, \mathrm{ka}_{2}, \mathrm{ka}_{1} ; \mathrm{kb}_{2}, \mathrm{ka}_{3}, \mathrm{ka}_{2}, \mathrm{~kb}_{1}\right)$

$\tilde{\mathrm{A}}^{\mathrm{i}} \oplus \widetilde{\mathrm{B}}^{\mathrm{i}} \cong\left(\mathrm{a}_{1}+\mathrm{n}_{1}, \mathrm{a}_{2}+\mathrm{n}_{2}, \mathrm{a}_{3}+\mathrm{n}_{3}, \mathrm{a}_{4}+\mathrm{n}_{4}\right.$;

$\left.\mathrm{b}_{1}+\mathrm{m}_{1}, \mathrm{a}_{2}+\mathrm{n}_{2}, \mathrm{a}_{3}+\mathrm{n}_{3}, \mathrm{~b}_{2}+\mathrm{m}_{2}\right)$

$\tilde{\mathrm{A}}^{\mathrm{i} \ominus} \widetilde{\mathrm{B}}^{\mathrm{i}} \cong\left(\mathrm{a}_{1}-\mathrm{n}_{4}, \mathrm{a}_{2}-\mathrm{n}_{3}, \mathrm{a}_{3}-\mathrm{n}_{2}, \mathrm{a}_{4}-\mathrm{n}_{1}\right.$;

$\left.\mathrm{b}_{1}-\mathrm{m}_{2}, \mathrm{a}_{2}-\mathrm{n}_{3}, \mathrm{a}_{3}-\mathrm{n}_{2}, \mathrm{~b}_{2}-\mathrm{m}_{1}\right)$

$\tilde{\mathrm{A}}^{\mathrm{i}} \otimes \widetilde{\mathrm{B}}^{\mathrm{i}} \cong\left(\mathrm{a}_{1} \mathrm{n}_{1}, \mathrm{a}_{2} \mathrm{n}_{2}, \mathrm{a}_{3} \mathrm{n}_{3}, \mathrm{a}_{4} \mathrm{n}_{4}\right.$

$\left.\mathrm{b}_{1} \mathrm{~m}_{1}, \mathrm{a}_{2} \mathrm{n}_{2}, \mathrm{a}_{3} \mathrm{n}_{3}, \mathrm{~b}_{2} \mathrm{~m}_{2}\right)\left(\tilde{\mathrm{A}}^{\mathrm{i}}>0, \widetilde{\mathrm{B}}^{\mathrm{i}}>0\right)$

$\tilde{\mathrm{A}}^{\mathrm{i}} \otimes \widetilde{\mathrm{B}}^{\mathrm{i}} \cong\left(\mathrm{a}_{1} \mathrm{n}_{4}, \mathrm{a}_{2} \mathrm{n}_{3}, \mathrm{a}_{3} \mathrm{n}_{2}, \mathrm{a}_{4} \mathrm{n}_{1}\right.$ $\left.\mathrm{b}_{1} \mathrm{~m}_{2}, \mathrm{a}_{2} \mathrm{n}_{3}, \mathrm{a}_{3} \mathrm{n}_{2}, \mathrm{~b}_{2} \mathrm{~m}_{1}\right)\left(\tilde{\mathrm{A}}^{\mathrm{i}>}>0, \widetilde{\mathrm{B}}^{\mathrm{i}}<0\right)$

$\tilde{\mathrm{A}}^{\mathrm{i}} \otimes \widetilde{\mathrm{B}}^{\mathrm{i}} \cong\left(\mathrm{a}_{4} \mathrm{n}_{4}, \mathrm{a}_{3} \mathrm{n}_{3}, \mathrm{a}_{2} \mathrm{n}_{2}, \mathrm{a}_{1} \mathrm{n}_{1}\right.$

$\left.\mathrm{b}_{2} \mathrm{~m}_{2}, \mathrm{a}_{3} \mathrm{n}_{3}, \mathrm{a}_{2} \mathrm{n}_{2}, \mathrm{~b}_{1} \mathrm{~m}_{1}\right)\left(\tilde{\mathrm{A}}^{\mathrm{i}<0}, \widetilde{\mathrm{B}}^{\mathrm{i}<0}\right)$

$\tilde{\mathrm{A}}^{\mathrm{i} \oslash} \widetilde{\mathrm{B}}^{\mathrm{i}} \cong\left(\mathrm{a}_{1} / \mathrm{n}_{4}, \mathrm{a}_{2} / \mathrm{n}_{3}, \mathrm{a}_{3} / \mathrm{n}_{2}, \mathrm{a}_{4} / \mathrm{n}_{1}\right.$;

$\left.\mathrm{b}_{1} / \mathrm{m}_{2}, \mathrm{a}_{2} / \mathrm{n}_{3}, \mathrm{a}_{3} / \mathrm{n}_{2}, \mathrm{~b}_{2} / \mathrm{m}_{1}\right)\left(\tilde{\mathrm{A}}^{\mathrm{i}>0}, \widetilde{\mathrm{B}}^{\mathrm{i}}>0\right)$

$\tilde{\mathrm{A}}^{\mathrm{i}} \oslash \widetilde{\mathrm{B}} \tilde{\mathrm{i}} \cong\left(\mathrm{a}_{1} / \mathrm{n}_{1}, \mathrm{a}_{2} / \mathrm{n}_{2}, \mathrm{a}_{3} / \mathrm{n}_{3}, \mathrm{a}_{4} / \mathrm{n}_{4}\right.$;

$\left.\mathrm{b}_{1} / \mathrm{m}_{1}, \mathrm{a}_{2} / \mathrm{n}_{2}, \mathrm{a}_{3} / \mathrm{n}_{3}, \mathrm{~b}_{2} / \mathrm{m}_{2}\right)\left(\tilde{\mathrm{A}}^{\mathrm{i}}>0, \widetilde{\mathrm{B}}^{\mathrm{i}}<0\right)$

$\tilde{\mathrm{A}}^{\mathrm{i}} \oslash \widetilde{\mathrm{B}} \tilde{\mathrm{i}} \cong\left(\mathrm{a}_{4} / \mathrm{n}_{1}, \mathrm{a}_{3} / \mathrm{n}_{2}, \mathrm{a}_{2} / \mathrm{n}_{3}, \mathrm{a}_{1} / \mathrm{n}_{4}\right.$;

$\left.\mathrm{b}_{2} / \mathrm{m}_{1}, \mathrm{a}_{3} / \mathrm{n}_{2}, \mathrm{a}_{2} / \mathrm{n}_{3}, \mathrm{~b}_{1} / \mathrm{m}_{2}\right)\left(\tilde{\mathrm{A}}^{\left.\mathrm{i}<0, \widetilde{\mathrm{B}}^{\mathrm{i}}<0\right)}\right.$

The reason why it is approximately accurate is that the functions of membership and non-membership degrees can change. Critical values remain exactly the same. If Nagoorgani and Ponnalagu's (2012) expected value proposal were adapted to trapezoidal intuitionistic fuzzy numbers, the expected value proposed for triangular intuitionistic fuzzy numbers is:

$\mathrm{E}\left(\tilde{\mathrm{A}}^{\mathrm{i}}\right)=\left(\mathrm{a}_{1}+2 \mathrm{a}_{2}+2 \mathrm{a}_{3}+\mathrm{a}_{4}+\mathrm{b}_{1}+\mathrm{b}_{2}\right) / 8$

Arithmetic Aggregation:

$\widetilde{\mathrm{A}}^{\mathrm{i}} \cong\left(\left(\sum_{\mathrm{k}=1}^{\mathrm{K}} \mathrm{a}_{1 \mathrm{k}}\right) / \mathrm{K},\left(\sum_{\mathrm{k}=1}^{\mathrm{K}} \mathrm{a}_{2 \mathrm{k}}\right) / \mathrm{K},\left(\sum_{\mathrm{k}=1}^{\mathrm{K}} \mathrm{a}_{3 \mathrm{k}}\right) / \mathrm{K},\left(\sum_{\mathrm{k}=1}^{\mathrm{K}} \mathrm{a}_{4 \mathrm{k}}\right) / \mathrm{K}\right.$; $\left.\left(\sum_{\mathrm{k}=1}^{\mathrm{K}} \mathrm{b}_{1 \mathrm{k}}\right) / \mathrm{K},\left(\sum_{\mathrm{k}=1}^{\mathrm{K}} \mathrm{a}_{2 \mathrm{k}}\right) / \mathrm{K},\left(\sum_{\mathrm{k}=1}^{\mathrm{K}} \mathrm{a}_{3 \mathrm{k}}\right) / \mathrm{K},\left(\sum_{\mathrm{k}=1}^{\mathrm{K}} \mathrm{b}_{2 \mathrm{k}}\right) / \mathrm{K}\right)$

Geometric Aggregation: $\widetilde{\mathrm{A}}^{\mathrm{i}}$

$\cong\left(\left(\prod_{\mathrm{k}=1}^{\mathrm{K}} \mathrm{a}_{1 \mathrm{k}}\right)^{1 / \mathrm{K}},\left(\prod_{\mathrm{k}=1}^{\mathrm{K}} \mathrm{a}_{2 \mathrm{k}}\right)^{1 / \mathrm{K}},\left(\prod_{\mathrm{k}=1}^{\mathrm{K}} \mathrm{a}_{3 \mathrm{k}}\right)^{1 / \mathrm{K}},\left(\prod_{\mathrm{k}=1}^{\mathrm{K}} \mathrm{a}_{4 \mathrm{k}}\right)^{1 / \mathrm{K}}\right.$; $\left.\left(\prod_{\mathrm{k}=1}^{\mathrm{K}} \mathrm{b}_{1 \mathrm{k}}\right)^{1 / \mathrm{K}},\left(\prod_{\mathrm{k}=1}^{\mathrm{K}} \mathrm{a}_{2 \mathrm{k}}\right)^{1 / \mathrm{K}},\left(\prod_{\mathrm{k}=1}^{\mathrm{K}} \mathrm{a}_{3 \mathrm{k}}\right)^{1 / \mathrm{K}},\left(\prod_{\mathrm{k}=1}^{\mathrm{K}} \mathrm{b}_{2 \mathrm{k}}\right)^{1 / \mathrm{K}}\right)(23)$

\section{Intuitionistic Fuzzy Real-Option Valuation}

Solar energy investments require high level of investment costs and also involve high level of uncertainty in their future cash flows. The classical investment analysis techniques do not consider the probabilistic nature of these kind of investments because of their static point of views. Real option valuation models present excellent tools to consider the uncertainty including vagueness and impreciseness.

Carlsson and Fuller modeled Merton's more developed version of the option pricing theory proposed by Black and Scholes with trapezoidal fuzzy numbers. In this study, this model is formulated with trapezoidal intuitionistic fuzzy numbers rather than trapezoidal fuzzy numbers.

Intuitionistic fuzzy numbers hold more information than type-1 fuzzy numbers and can be considered as a generalized version of type-1 fuzzy numbers. Decision makers need more informative models to evaluate the projects that have a high degree of uncertainty. The necessity of estimating the expected cash flows and the costs by the trapezoidal possibility distribution, in which the volatility variable in the real-options theory would not be sufficient to express uncertainty, revealed the need for Carlsson and Fuller to use fuzzy numbers in the realoptions theory. On the other hand, the uncertainty of the investment environment in the developing countries highlights the need for an inclusive model with additional information on investment projects. Real-option valuation with intuitionistic fuzzy numbers will meet the need for this model in valuation of investment decisions in the market where more uncertainty is experienced. Furthermore, hesitation of the decision makers and the market conditions will be transferred to the investment 
project valuation model, which is the intuitionistic nature of fuzzy numbers.

Any uncertainty regarding the investment conditions of an investment project in the coming years will increase anyway. The operation nature of intuitionistic fuzzy numbers will tend to increase the variability in cash flows and costs over the coming years and will adapt to the growing uncertainty of investment conditions. Besides, managerial flexibility such as postponement of investment decisions, capacity increase, and growth will be more comprehensive in the valuation model.

These numbers are used as the intuitionistic trapezoidal number in this model, aiming at investment decisions valuation, because of the above reasons and the fact that the expected cash flows and the expected cost should include more information. On the other hand, the reason why the value of hesitation for the most possible value range is removed is the idea of reducing the uncertainty of most possible value ranges. Uncertainty must always increase toward the margins. Regardless of the market, further certainty in the most possible value range of the model, which is at least the expectation of the market and the observational preference of those who have decided on investment processes (experts).

Step 1: Intuitionistic fuzzy present value of expected cash flows is obtained by using Eqs. (24-25). The present value is illustrated in Figure 3.

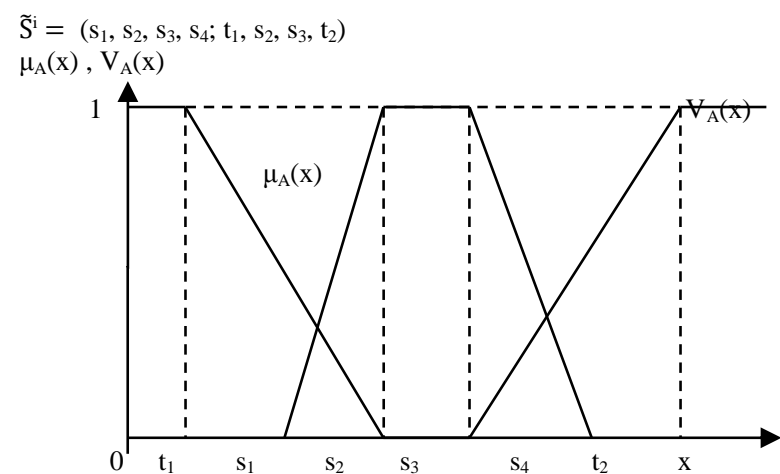

Figure 3: Intuitionistic Fuzzy Present Value of Expected Cash Flows

In other words, the current intuitionistic fuzzy values of expected cash flows are obtained by providing the intuitionistic fuzzy values of future cash flows with the weighted average cost of capital (WACC) today as follows: $\widetilde{\mathrm{S}}^{\mathrm{i}}=\left(\widetilde{\mathrm{CF}^{\mathrm{i}}}\right)_{1}+\left(\widetilde{\mathrm{CF}^{\mathrm{i}}}\right)_{2}+\left(\widetilde{\mathrm{CF}^{\mathrm{i}}}\right)_{3}+\ldots \ldots+\left(\widetilde{\mathrm{CF}^{\mathrm{i}}}\right)_{\mathrm{T}}$ $=\sum_{\mathrm{t}=1}^{\mathrm{T}}(\widetilde{\mathrm{CF}})_{\mathrm{t}}^{\mathrm{i}} /(1+\mathrm{WACC})^{\mathrm{t}}$

If investment decision is thought to be a solar energy investment, cash flows can be function of electricity prices (EP), incentives (INC), efficiency rate (ER), interest rate (IR), amortization rate (AR), tax rate (TR), operational costs $(\mathrm{OC})$, exchange rate $(\mathrm{EX})$ and these variables can be used as intuitionistic trapezoidal fuzzy numbers.

$\left(\widetilde{\mathrm{CF}}^{\mathrm{i}}\right)_{\mathrm{t}}=\mathrm{f}\left(\left(\widetilde{\mathrm{EP}}^{\mathrm{i}}\right)_{\mathrm{t}},\left(\widetilde{\mathrm{INC}}^{\mathrm{i}}\right)_{\mathrm{t}},\left(\widetilde{\mathrm{ER}}^{\mathrm{i}}\right)_{\mathrm{t}},\left(\widetilde{\mathrm{IR}}^{\mathrm{i}}\right)_{\mathrm{t}},\left(\widetilde{\mathrm{AR}}^{\mathrm{i}}\right)_{\mathrm{t}},\left(\widetilde{\mathrm{TR}}^{\mathrm{i}}\right)_{\mathrm{t}},\left(\widetilde{\mathrm{OC}}^{\mathrm{i}}\right)_{\mathrm{t}}\right.$, $\left.\left(\widetilde{\mathrm{EX}^{\mathrm{i}}}\right)_{\mathrm{t}}, \ldots ..\right)$

The details of Eq. (25) are given in the application section.

Step 2: Intuitionistic fuzzy value of the expected investment cost is obtained based on experts knowledge on solar energy investments.
$\widetilde{\mathrm{X}}^{\mathrm{i}}=\left(\mathrm{x}_{1}, \mathrm{x}_{2}, \mathrm{x}_{3}, \mathrm{x}_{4} ; \mathrm{y}_{1}, \mathrm{x}_{2}, \mathrm{x}_{3}, \mathrm{y}_{2}\right)$

Step 3: Expected values are calculated by Eqs. (26-27):

$\mathrm{E}\left(\widetilde{\mathrm{S}}^{\mathrm{i}}\right)=\left(\mathrm{s}_{1}+2 \mathrm{~s}_{2}+2 \mathrm{~s}_{3}+\mathrm{s}_{4}+\mathrm{t}_{1}+\mathrm{t}_{2}\right) / 8$

$\mathrm{E}\left(\widetilde{\mathrm{X}}^{\mathrm{i}}\right)=\left(\mathrm{x}_{1}+2 \mathrm{x}_{2}+2 \mathrm{x}_{3}+\mathrm{x}_{4}+\mathrm{y}_{1}+\mathrm{y}_{2}\right) / 8$

If the decision maker demonstrates a risk-averse approach, this situation can increase the potential of critical values in the range of the most possible value. If we consider that a first-guess value calculation can be used by a risk-seeker decision maker, then the expected value for a risk-averse investor can be expressed by Eqs. (28-29):

$\mathrm{E}\left(\tilde{\mathrm{S}}^{\mathrm{i}}\right)=\left(\mathrm{s}_{1}+4 \mathrm{~s}_{2}+4 \mathrm{~s}_{3}+\mathrm{s}_{4}+\mathrm{t}_{1}+\mathrm{t}_{2}\right) / 12$

$\mathrm{E}\left(\widetilde{\mathrm{X}}^{\mathrm{i}}\right)=\left(\mathrm{x}_{1}+4 \mathrm{x}_{2}+4 \mathrm{x}_{3}+\mathrm{x}_{4}+\mathrm{y}_{1}+\mathrm{y}_{2}\right) / 12$

The weight of the maximum-value range critical values may vary depending on the investor's decision as a risk perception indicator. In general terms, the expected values can be shown as:

$\mathrm{E}\left(\widetilde{\mathrm{S}}^{\mathrm{i}}\right)=\left(\mathrm{s}_{1}+\mathrm{ks}_{2}+\mathrm{ks}_{3}+\mathrm{s}_{4}+\mathrm{t}_{1}+\mathrm{t}_{2}\right) /(4+2 \mathrm{k})$

$\mathrm{E}\left(\widetilde{\mathrm{X}}^{\mathrm{i}}\right)=\left(\mathrm{x}_{1}+\mathrm{kx}_{2}+\mathrm{kx}_{3}+\mathrm{x}_{4}+\mathrm{y}_{1}+\mathrm{y}_{2}\right) /(4+2 \mathrm{k})$

The standard deviation calculation based on frequencies ( $\mathrm{f}(\mathrm{x})$ ) is integrated into this model by looking at the expected values and variance $(\mathrm{X})=\mathrm{E}\left(\mathrm{X}^{2}\right)-\mathrm{E}(\mathrm{X})^{2}$. Thus, our variance is expressed as:

$\sigma^{2}\left(\widetilde{\mathrm{S}}^{\mathrm{i}}\right)=\left(\mathrm{f}\left(\mathrm{s}_{1}\right)\left(\mathrm{s}_{1}-\mathrm{E}\left(\widetilde{\mathrm{S}}^{\mathrm{i}}\right)\right)^{2}\right)+\left(\mathrm{f}\left(\mathrm{s}_{2}\right)\left(\mathrm{s}_{2}-\mathrm{E}\left(\widetilde{\mathrm{S}}^{\mathrm{i}}\right)\right)^{2}\right)+\left(\mathrm{f}\left(\mathrm{s}_{3}\right)\left(\mathrm{s}_{3}-\mathrm{E}\left(\widetilde{\mathrm{S}}^{\mathrm{i}}\right)\right)^{2}\right)$

$+\left(\mathrm{f}\left(\mathrm{s}_{4}\right)\left(\mathrm{s}_{4}-\mathrm{E}\left(\widetilde{\mathrm{S}}^{\mathrm{i}}\right)\right)^{2}\right)+\left(\mathrm{f}\left(\mathrm{t}_{1}\right)\left(\mathrm{t}_{1}-\mathrm{E}\left(\widetilde{\mathrm{S}}^{\mathrm{i}}\right)\right)^{2}\right)+\left(\mathrm{f}\left(\mathrm{t}_{2}\right)\left(\mathrm{t}_{2}-\mathrm{E}\left(\widetilde{\mathrm{S}}^{\mathrm{i}}\right)\right)^{2}\right)$

If the frequencies in the expected value expression are used for the risk-seeking decision maker used in the preceding sections, the expression becomes:

$\sigma^{2}\left(\widetilde{\mathrm{S}}^{\mathrm{i}}\right)=\left((1 / 8)\left(\mathrm{s}_{1}-\mathrm{E}\left(\widetilde{\mathrm{S}}^{\mathrm{i}}\right)\right)^{2}\right)+\left((1 / 4)\left(\mathrm{s}_{2}-\mathrm{E}\left(\widetilde{\mathrm{S}}^{\mathrm{i}}\right)\right)^{2}\right)+\left((1 / 4)\left(\mathrm{s}_{3}-\mathrm{E}\left(\widetilde{\mathrm{S}}^{\mathrm{i}}\right)\right)^{2}\right)$ $+\left((1 / 8)\left(\mathrm{s}_{4}-\mathrm{E}\left(\widetilde{\mathrm{S}}^{\mathrm{i}}\right)\right)^{2}\right)+\left((1 / 8)\left(\mathrm{t}_{1}-\mathrm{E}\left(\widetilde{\mathrm{S}}^{\mathrm{i}}\right)\right)^{2}\right)+\left((1 / 8)\left(\mathrm{t}_{2}-\mathrm{E}\left(\widetilde{\mathrm{S}}^{\mathrm{i}}\right)\right)^{2}\right)$

For the risk-averse decision maker:

$\sigma^{2}\left(\widetilde{\mathrm{S}}^{\mathrm{i}}\right)=\left((1 / 12)\left(\mathrm{s}_{1}-\mathrm{E}\left(\widetilde{\mathrm{S}}^{\mathrm{i}}\right)\right)^{2}\right)+\left((1 / 3)\left(\mathrm{s}_{2}-\mathrm{E}\left(\widetilde{\mathrm{S}}^{\mathrm{i}}\right)\right)^{2}\right)+\left((1 / 3)\left(\mathrm{s}_{3}-\mathrm{E}\left(\widetilde{\mathrm{S}}^{\mathrm{i}}\right)\right)^{2}\right)$ $+\left((1 / 12)\left(\mathrm{s}_{4}-\mathrm{E}\left(\widetilde{\mathrm{S}}^{\mathrm{i}}\right)\right)^{2}\right)+\left((1 / 12)\left(\mathrm{t}_{1}-\mathrm{E}\left(\widetilde{\mathrm{S}}^{\mathrm{i}}\right)\right)^{2}\right)$

$+\left((1 / 12)\left(\mathrm{t}_{2}-\mathrm{E}\left(\tilde{\mathrm{S}}^{\mathrm{i}}\right)\right)^{2}\right)$

In the model, the value obtained from the portion of the expected value of cash flows for standardizing the use of the model in which the variance is converted to standard deviation by taking the square root is used as volatility:

$\sigma=\sigma\left(\widetilde{\mathrm{S}}^{\mathrm{i}}\right) / \mathrm{E}\left(\widetilde{\mathrm{S}}^{\mathrm{i}}\right)$

In addition to this variance calculation, historical volatility used in the classical option or real option valuation is also used for comparison purposes. $n+1$ observation number, $V_{j} \mathrm{j}$. underlying security price at the end of term, $T$ annual time interval, $u_{j}$ variable is defined as below:

$\mathrm{u}_{\mathrm{j}}=\ln \left(\mathrm{V}_{\mathrm{j}} / \mathrm{V}_{\mathrm{j}-1}\right)$

$\mathrm{v}=\sqrt{ }\left[(1 / \mathrm{n}-1) \sum\left(\mathrm{u}_{\mathrm{j}}-\overline{\mathrm{u}}\right)^{2}\right]$

$\mathrm{j}=1,2, \ldots, \mathrm{n}$.

" $\bar{u}$ " is the mean of " $u_{j}$ "s.

Finally, volatility is calculated:

$\sigma=\mathrm{v} / \sqrt{\mathrm{T}}$

Expected value expressions within the cumulative standard normal distribution variable can be found in different forms for two risk-seeking and risk-averse decision makers. Moreover, frequencies and standard deviation calculations and historical volatility can be used 
over the expected values for risk-seeking and risk-averse investors for volatility. These three volatility accounts are comparable. In addition, the decision maker may prefer one of these calculations according to the investment environment and the type of investment.

Once the cumulative standard normal distribution variance has been calculated, the expected cash flows and expected cost enter the operation with the intuitionistic trapezoidal fuzzy number.

Step 4: Intuitionistic fuzzy real-option value (IFROV) is calculated by using Eqs. (39-41).

$\tilde{\mathrm{C}}^{\mathrm{i}} \cong\left(\mathrm{c}_{1}, \mathrm{c}_{2}, \mathrm{c}_{3}, \mathrm{c}_{4} ; \mathrm{d}_{1}, \mathrm{c}_{2}, \mathrm{c}_{3}, \mathrm{~d}_{2}\right)$

$\mathrm{t}=$ Remaining option time (time to maturity)

$\sigma=$ Standard deviation of cash flows (volatility)

$\mathrm{r}=$ Risk-free interest rate

$\mathrm{N}(\mathrm{d})=$ Cumulative standard normal distribution

$\widetilde{\mathrm{C}}^{\mathrm{i}}=\widetilde{\mathrm{S}}^{\mathrm{i}} \mathrm{e}^{-(\delta \mathrm{t})} \mathrm{N}\left(\mathrm{d}_{1}\right)-\widetilde{\mathrm{X}}^{\mathrm{i}} \mathrm{e}^{-(\mathrm{rt})} \mathrm{N}\left(\mathrm{d}_{2}\right)$

$\mathrm{d}_{1}=\left[\ln \left(\mathrm{E}\left(\widetilde{\mathrm{S}}^{\mathrm{i}}\right) / \mathrm{E}\left(\widetilde{\mathrm{X}}^{\mathrm{i}}\right)\right)+\left(\mathrm{r}-\delta+\sigma^{2} / 2\right) \mathrm{t}\right] /(\sigma \sqrt{\mathrm{t}})$

$\mathrm{d}_{2}=\left[\ln \left(\mathrm{E}\left(\widetilde{\mathrm{S}}^{\mathrm{i}}\right) / \mathrm{E}\left(\widetilde{\mathrm{X}}^{\mathrm{i}}\right)\right)+\left(\mathrm{r}-\delta-\sigma^{2} / 2\right) \mathrm{t}\right] /(\sigma \sqrt{\mathrm{t}})=\mathrm{d}_{1}-\sigma \sqrt{\mathrm{t}}(41)$

Without dividend distribution assumption, the calculations are:

IFROV $=\left(\mathrm{s}_{1}, \mathrm{~s}_{2}, \mathrm{~s}_{3}, \mathrm{~s}_{4} ; \mathrm{t}_{1}, \mathrm{~s}_{2}, \mathrm{~s}_{3}, \mathrm{t}_{2}\right) \mathrm{N}\left(\mathrm{d}_{1}\right)$

$-\left(\mathrm{x}_{1}, \mathrm{x}_{2}, \mathrm{x}_{3}, \mathrm{x}_{4} ; \mathrm{y}_{1}, \mathrm{x}_{2}, \mathrm{x}_{3}, \mathrm{y}_{2}\right) \mathrm{e}^{-(\mathrm{rT})} \mathrm{N}\left(\mathrm{d}_{2}\right)$

$\mathrm{IFROV} \cong\left(\mathrm{s}_{1} \mathrm{~N}\left(\mathrm{~d}_{1}\right)-\mathrm{x}_{4} \mathrm{e}^{-(\mathrm{rT})} \mathrm{N}\left(\mathrm{d}_{2}\right), \mathrm{s}_{2} \mathrm{~N}\left(\mathrm{~d}_{1}\right)-\mathrm{x}_{3} \mathrm{e}^{-(\mathrm{rT})} \mathrm{N}\left(\mathrm{d}_{2}\right)\right.$,

$\mathrm{S}_{3} \mathrm{~N}\left(\mathrm{~d}_{1}\right)-\mathrm{x}_{2} \mathrm{e}^{-(\mathrm{rT})} \mathrm{N}\left(\mathrm{d}_{2}\right), \mathrm{s}_{4} \mathrm{~N}\left(\mathrm{~d}_{1}\right)-\mathrm{x}_{1} \mathrm{e}^{-(\mathrm{rT})} \mathrm{N}\left(\mathrm{d}_{2}\right) ; \mathrm{t}_{1} \mathrm{~N}\left(\mathrm{~d}_{1}\right)$

$-\mathrm{y}_{2} \mathrm{e}^{-(\mathrm{rT})} \mathrm{N}\left(\mathrm{d}_{2}\right), \mathrm{s}_{2} \mathrm{~N}\left(\mathrm{~d}_{1}\right)-\mathrm{x}_{3} \mathrm{e}^{-(\mathrm{rT})} \mathrm{N}\left(\mathrm{d}_{2}\right), \mathrm{s}_{3} \mathrm{~N}\left(\mathrm{~d}_{1}\right)-\mathrm{x}_{2} \mathrm{e}^{-(\mathrm{rT})} \mathrm{N}\left(\mathrm{d}_{2}\right)$,

$\left.\mathrm{t}_{2} \mathrm{~N}\left(\mathrm{~d}_{1}\right)-\mathrm{y}_{1} \mathrm{e}^{-(\mathrm{rT})} \mathrm{N}\left(\mathrm{d}_{2}\right)\right)$

As Carlsson and Fuller explain, the possibilistic realoption value and the possible expected value of the IFROV can be equal only if the intuitionistic real-option value is symmetric. However, this condition is a coincidence.

Step 5: While it is determined to invest, the basic criterion is the expanded net present value. According to Trigeorgis [16], the profitability of a project can be evaluated by Eq. (44):

Expanded NPV $=$ Classical NPV + Option Premium

Expanded intuitionistic fuzzy net present value is then calculated by Eq. (45):

$($ EIFNPV $)=$ Intuitionistic fuzzy net present value $($ IFNPV) + Intuitionistic fuzzy real-option value (IFROV)

In another notation:

$\left(\widetilde{\mathrm{ENPV}}^{\mathrm{i}}\right)_{\mathrm{t}}=\left(\widetilde{\mathrm{NPV}}^{\mathrm{i}}\right)_{\mathrm{t}}+\left(\widetilde{\mathrm{ROV}}^{\mathrm{i}}\right)_{\mathrm{t}}$

$\left(\overline{\mathrm{NPV}}^{\mathrm{i}}\right)_{\mathrm{t}}=\left(\mathrm{s}_{1}, \mathrm{~s}_{2}, \mathrm{~s}_{3}, \mathrm{~s}_{4} ; \mathrm{t}_{1}, \mathrm{~s}_{2}, \mathrm{~s}_{3}, \mathrm{t}_{2}\right)_{\mathrm{t}}$

$-\left(\left(\mathrm{x}_{1}, \mathrm{x}_{2}, \mathrm{x}_{3}, \mathrm{x}_{4} ; \mathrm{y}_{1}, \mathrm{x}_{2}, \mathrm{x}_{3}, \mathrm{y}_{2}\right)_{\mathrm{t}} /(1+\mathrm{WACC})^{\mathrm{t}}\right)$

$\left(\mathrm{ENPV}^{\mathrm{i}}\right)_{\mathrm{t}}=\left(\mathrm{s}_{1}, \mathrm{~s}_{2}, \mathrm{~s}_{3}, \mathrm{~s}_{4} ; \mathrm{t}_{1}, \mathrm{~s}_{2}, \mathrm{~s}_{3}, \mathrm{t}_{2}\right)_{\mathrm{t}}$

$-\left(\left(\mathrm{x}_{1}, \mathrm{x}_{2}, \mathrm{x}_{3}, \mathrm{x}_{4} ; \mathrm{y}_{1}, \mathrm{x}_{2}, \mathrm{x}_{3}, \mathrm{y}_{2}\right) \mathrm{t} /(1+\mathrm{WACC})^{\mathrm{t}}\right)$

$+\left(\mathrm{c}_{1}, \mathrm{c}_{2}, \mathrm{c}_{3}, \mathrm{c}_{4} ; \mathrm{d}_{1}, \mathrm{c}_{2}, \mathrm{c}_{3}, \mathrm{~d}_{2}\right)$,

$\left(\overline{E N P V}^{\mathrm{i}}\right)_{\mathrm{t}} \cong\left(\mathrm{s}_{1}-\mathrm{x}_{4}(1+\mathrm{WACC})^{\mathrm{t}}+\mathrm{c}_{1}, \mathrm{~s}_{2}-\mathrm{x}_{3}(1+\mathrm{WACC})^{\mathrm{t}}+\mathrm{c}_{2}\right.$, $\mathrm{s}_{3}-\mathrm{x}_{2}(1+\mathrm{WACC})^{\mathrm{t}}+\mathrm{c}_{3}, \mathrm{~s}_{4}-\mathrm{x}_{1}(1+\mathrm{WACC})^{\mathrm{t}}+\mathrm{c}_{4} ; \mathrm{t}_{1}-$

$\mathrm{y}_{2}(1+\mathrm{WACC})^{\mathrm{t}}+\mathrm{d}_{1}, \mathrm{~s}_{2}-\mathrm{x}_{3}(1+\mathrm{WACC})^{\mathrm{t}}+\mathrm{c}_{2}, \mathrm{~s}_{3}-\mathrm{x}_{2}(1+\mathrm{WACC})^{\mathrm{t}}$

$\left.+\mathrm{c}_{3}, \mathrm{t}_{2}-\mathrm{y}_{1}(1+\mathrm{WACC})^{\mathrm{t}}+\mathrm{d}_{2}\right)$

Letter notation can be shortened as follows:

$(\widetilde{E N P V})^{\mathrm{i}}=\left(\mathrm{e}_{1}, \mathrm{e}_{2}, \mathrm{e}_{3}, \mathrm{e}_{4} ; \mathrm{f}_{1}, \mathrm{e}_{2}, \mathrm{e}_{3}, \mathrm{f}_{2}\right)_{\mathrm{t}}$

Step 6: Among the expanded net present values for each current investment year, the year with the maximum intuitionistic fuzzy number value is considered as the optimum investment year $\left(\mathrm{t}^{*}\right)$ as in Eq. (50):
$\left(\widetilde{\mathrm{ENPV}}^{\mathrm{i}}\right)_{\mathrm{t}^{*}}=\max _{\mathrm{t}=0,1,2, \ldots, \mathrm{T}}\left(\widetilde{\mathrm{ENPV}}^{\mathrm{i}}\right)_{\mathrm{t}}$

For this comparison, defuzzification is performed by the expected value of the intuitionistic fuzzy. According to risk-averse and risk-seeking decision-makers as in Eqs. (51-52):

$\mathrm{E}\left(\widetilde{\mathrm{ENPV}}^{\mathrm{i}}\right)=\left(\mathrm{e}_{1}+2 \mathrm{e}_{2}+2 \mathrm{e}_{3}+\mathrm{e}_{4}+\mathrm{f}_{1}+\mathrm{f}_{2}\right) / 8$
$\mathrm{E}\left(\widetilde{\mathrm{ENPV}}^{\mathrm{i}}\right)=\left(\mathrm{e}_{1}+4 \mathrm{e}_{2}+4 \mathrm{e}_{3}+\mathrm{e}_{4}+\mathrm{f}_{1}+\mathrm{f}_{2}\right) / 12$

\section{Illustrative Example}

The main topic of the study is the Real Option Valuation with Intuitionistic Fuzzy Numbers. In the explanatory example, it will be examined whether the investment of licensed photovoltaic solar energy, which does not seem profitable for Turkey today, will be profitable in the next 15 years, and the most profitable year, itself. The use of 3 different approaches to the variance account will give 3 different views to the study. In fact, our ultimate goal is to reach the expanded present net value. To achieve this goal, various assumptions, models and market data should be used. Here are the definitions of how each variable in the model is used in this context.

\section{Electricity Prices and Electricity Price Changes}

There is no production in the first year. A state purchase guarantee for $\$ 13.3$ cents / $\mathrm{kWh}$ will be available for the next 10 years. Euro/Dollar parity $=(1.06,1.09$, $1.12,1.15 ; 1.03,1.09,1.12,1.18$ )

But, it is foreseen that this purchase guarantee, which is valid for companies to operate until the end of 2020, will not continue in the same way after this date. The change in the purchase guarantee is transferred to the model with the geometric aggregation decision-making process.

Table 1

Purchase Guarantee Change with the Geometric Aggregation Decision-Making Process

\begin{tabular}{|c|c|}
\hline DM1 & $(0.71,0.72,0.73,0.74 ; 0.70,0.72,0.73,0.75)$ \\
\hline DM2 & $(0.63,0.66,0.69,0.72 ; 0.60,0.66,0.69,0.75)$ \\
\hline DM3 & $(0.63,0.66,0.69,0.72 ; 0.60,0.66,0.69,0.75)$ \\
\hline FINAL & $(0.66,0.68,0.70,0.73 ; 0.63,0.68,0.70,0.75)$ \\
\hline
\end{tabular}

So it will be: $(7.58,8.07,8.58,9.12 ; 7.12,8.07,8.58$, 9.68) Euro cent / kWh.

After a period of ten years of warranted purchase, licensed companies will be able to sell at the market the electricity that they produce. For this reason, starting from today, the change of electricity prices should be calculated. These changes are used by translating the percentage change interval to the intuitionistic trapezoidal number critical values with equal intervals, each valid for seven years. The 7-year estimates are then annualized. The decisions of the three decision makers are expressed as a percentage of the intuitionistic trapezoidal number, then aggregated with the geometric average. 


\begin{tabular}{|c|c|}
\hline \multicolumn{2}{|c|}{ Intuitionistic Fuzzy Electricity Price Variation Estimation } \\
\hline 1st-7th year & Yearly \\
\hline $\operatorname{dm} 1(-30 \%,-25 \%)$ & $\begin{array}{c}(0.952,0.954,0,956,0.958 ; 0.950,0.954 \\
0.956,0.960)\end{array}$ \\
\hline $\operatorname{dm} 2(-30 \%,-20 \%)$ & $\begin{array}{c}(0.954,0.958,0,962,0.966 ; 0.950,0.958 \\
0.962,0.970)\end{array}$ \\
\hline $\operatorname{dm} 3(-50 \%,-35 \%)$ & $\begin{array}{c}(0.912,0.919,0,926,0.933 ; 0.905,0.919 \\
0.926,0.940)\end{array}$ \\
\hline $\begin{array}{l}\text { 7- year total estimates in } \\
\text { the parenthesis }\end{array}$ & $\begin{array}{c}(0.939,0.944,0.948,0.952 ; 0.935,0.944 \\
0.948,0.957)\end{array}$ \\
\hline 8th-14th year & Yearly \\
\hline $\operatorname{dm} 1(-20 \%,-10 \%)$ & $\begin{array}{c}(0.973,0.976,0,979,0.982 ; 0.970,0.976, \\
0.979,0.985)\end{array}$ \\
\hline $\operatorname{dm} 2(-20 \%,-7 \%)$ & $\begin{array}{c}(0.974,0.978,0,982,0.986 ; 0.970,0.978, \\
0.982,0.990)\end{array}$ \\
\hline \multirow[t]{2}{*}{$\operatorname{dm} 3(-25 \%,-10 \%)$} & $\begin{array}{c}(0.965,0.970,0,975,0.980 ; 0.960,0.970 \\
0.975,0.985)\end{array}$ \\
\hline & $\begin{array}{c}(0.971,0.975,0.979,0.983 ; 0.967,0.975 \\
0.979,0.987)\end{array}$ \\
\hline 15th-21st year & Yearly \\
\hline $\operatorname{dm} 1(-10 \%, 7 \%)$ & $\begin{array}{c}(0.990,0.995,1.000,1.005 ; 0.985,0.995 \\
1.000,1.010)\end{array}$ \\
\hline $\operatorname{dm} 2(-16 \%, 4 \%)$ & $\begin{array}{c}(0.981,0.987,0,993,0.999 ; 0.975,0.987 \\
0.993,1.005)\end{array}$ \\
\hline \multirow[t]{2}{*}{$\operatorname{dm} 3(-16 \%, 0 \%)$} & $\begin{array}{c}(0.980,0.985,0,990,0.995 ; 0.975,0.985 \\
0.990,1.000)\end{array}$ \\
\hline & $\begin{array}{c}(0.984,0.989,0.994,1.000 ; 0.978,0.989 \\
0.994,1.005)\end{array}$ \\
\hline 22th year and after & Yearly \\
\hline dm1 & $\begin{array}{c}(0.994,0.998,1.002,1.006 ; 0.990,0.998, \\
1.002,1.010)\end{array}$ \\
\hline $\operatorname{dm} 2$ & $\begin{array}{c}(0.986,0.992,0.998,1.004 ; 0.980,0.992, \\
0.998,1.010)\end{array}$ \\
\hline \multirow[t]{2}{*}{$\mathrm{dm} 3$} & $\begin{array}{c}(0.984,0.988,0,992,0.996 ; 0.980,0.988 \\
0.992,1.000)\end{array}$ \\
\hline & $\begin{array}{c}(0.988,0.993,0.997,1.002 ; 0.983,0.993 \\
0.997,1.007)\end{array}$ \\
\hline
\end{tabular}

*Today electricity price is 4.3 Eurocent/kWh and in 12 th year: $(2.25,2.37$, $2.50,2.63 ; 2.13,2.37,2.50,2.78)$ Eurocent/kWh.

\section{Investment Costs and Investment Cost Variation Estimation}

The cost for the $20 \mathrm{MW}$ plant will be 20000000 Euros. On the other side, developed technology and supplydemand balance differ the initial investment costs every year. The scenario of change in initial cost investment in the form of expert opinion is predicted to change in 5 years as follows:

Table 3

Intuitionistic Fuzzy Investment Cost Variation Estimation (5Year Total Estimates in the Parenthesis)

\begin{tabular}{|c|c|}
\hline DM1 & Yearly \\
\hline Years $1-5(-30 \%,-10 \%)$ & $\begin{array}{c}(0.940,0.950,0.960,0.970 ; 0.930,0.950, \\
0.960,0.980)\end{array}$ \\
\hline Years 6-10 $(-16 \%,-5 \%)$ & $\begin{array}{c}(0.970,0.975,0.980,0.985 ; 0.965,0.975 \\
0.980,0.990)\end{array}$ \\
\hline Years $11-15(0 \%)$ & $\begin{array}{c}(1.000,1.000,1.000,1.000 ; 1.000,1.000, \\
1.000,1.000)\end{array}$ \\
\hline DM2 & Yearly \\
\hline Years $1-5(-29 \%,-18 \%)$ & $\begin{array}{c}(0.940,0.945,0.950,0.955 ; 0.935,0.945 \\
0.950,0.960)\end{array}$ \\
\hline Years $6-10(-14 \%,-2.5 \%)$ & $\begin{array}{c}(0.975,0.980,0.985,0.990 ; 0.970,0.980, \\
0.985,0.995)\end{array}$ \\
\hline Years $11-15(-12 \%, 0 \%)$ & $\begin{array}{c}(0.980,0.985,0.990,0.995 ; 0.975,0.985, \\
0.990,1.000)\end{array}$ \\
\hline
\end{tabular}

\begin{tabular}{|c|c|}
\hline DM3 & Yearly \\
\hline Years 1-5 $(-32 \%,-23 \%)$ & $\begin{array}{c}(0.930,0.935,0.940,0.945 ; 0.925,0.935, \\
0.940,0.950)\end{array}$ \\
\hline Years 11-15(-12\%, 0\%) & $\begin{array}{c}(0.980,0.985,0.990,0.995 ; 0.975,0.985 \\
0.990,1.000)\end{array}$ \\
\hline Years 11-15 $(0 \%)$ & $\begin{array}{c}(1.000,1.000,1.000,1.000 ; 1.000,1.000, \\
1.000,1.000)\end{array}$ \\
\hline Aggregations & Yearly \\
\hline Years 1-5 & $\begin{array}{c}(0.943,0.952,0.960,0.968 ; 0.935,0.952 \\
0.960,0.977)\end{array}$ \\
\hline Years 6-10 & $\begin{array}{c}(0.975,0.980,0.985,0.990 ; 0.970,0.980 \\
0.985,0.995)\end{array}$ \\
\hline Years 11-15 & $\begin{array}{c}(0.993,0.995,0.997,0.998 ; 0.992,0.995 \\
0.997,1.000)\end{array}$ \\
\hline
\end{tabular}

The parenthesized values are the total change intervals over 5 years. The margin values are assumed and then divided in equal intervals for each of the critical values of the intuitionistic trapezoidal number.

\section{Contribution Paid to the State}

Companies wishing to produce licensed solar energy have to pay contributions to the government. That contribution has been modeled with intuitionistic fuzzy numbers to overcome its uncertainty in the study.

First four year contribution for $20 \mathrm{MW}=(8,8.5,9$, 9.5; 7.5, 8.5, 9, 10) million Euros.

The contribution paid to the state will be determined by the decision makers with geometric aggregation models after 2020.

Table 4

Decrease in the Contribution Paid to the State in 2021

\begin{tabular}{|c|c|}
\hline $\begin{array}{l}\text { DM1 } \\
(-\% 85,-\% 75)\end{array}$ & $(0.17,0.19,0.21,0.23 ; 0.15,0.19,0.21,0.25)$ \\
\hline $\begin{array}{l}\text { DM2 } \\
(-\% 90,-\% 85) \\
\end{array}$ & $(0.11,0.12,0.13,0.14 ; 0.10,0.12,0.13,0.15)$ \\
\hline $\begin{array}{l}\text { DM3 } \\
(-\% 80,-\% 70)\end{array}$ & $(0.22,0.24,0.26,0.28 ; 0.20,0.24,0.26,0.30)$ \\
\hline FINAL & $(0.16,0.18,0.19,0.21 ; 0.14,0.18,0.19,0.22)$ \\
\hline
\end{tabular}

Table 5

Increase in the Contribution Paid to the State Annually After 2021

\begin{tabular}{|l|l|}
\hline DM1 (\%5, \%25) & $(1.09,1.13,1.17,1.21 ; 1.05,1.13,1.17,1.25)$ \\
\hline DM2 (\%0, \%15) & $(1.03,1.06,1.09,1.12 ; 1.00,1.06,1.09,1.15)$ \\
\hline DM3 (\%5, \%20) & $(1.08,1.11,1.14,1.17 ; 1.05,1.11,1.14,1.20)$ \\
\hline FINAL & $(1.07,1.10,1.13,1.17 ; 1.03,1.10,1.13,1.20)$ \\
\hline
\end{tabular}

\section{Annual Electricity Generation}

Today, with an annual investment to our southern regions, it is possible to generate $1752000 \mathrm{~kW}$ of energy per plant, on average 1 megawatts. The current output is calculated as follows:

$20000000 \mathrm{w} * 365$ day $* 24$ hour/day $*(0.197,0.199$, $0.201,0.203 ; 0.195,0.199,0.201,0.205)($ efficiency rate $)=$ (34514400, 34516152, 34863048, 35209944; 33822360, 34516152, 34863048, 35556840)

Yield ratios according to years have been determined according to expert opinion by considering factors such as developing technology, supply-demand balance and loss of potential investment points. For expert opinion, we have consulted with Gensed in Turkey. Since these efficiency 
Huseyin Yigit Ersen, Oktay Tas, Cengiz Kahraman. Intuitionistic Fuzzy Real-Options Theory and its Application to Solar...

ratios are considered as the average of expert opinions, no aggregation has been performed. The efficiency ratios used are as follows.

Table 6

Solar Panel Efficiency Rate

\begin{tabular}{|c|c|}
\hline Year & Efficiency rate \\
\hline $\mathbf{1}$ & $(0.202,0.204,0.206,0.208 ; 0.200,0.204,0.206,0.210)$ \\
\hline $\mathbf{2}$ & $(0.207,0.209,0.211,0.213 ; 0.205,0.209,0.211,0.215)$ \\
\hline $\mathbf{3}$ & $(0.212,0.214,0.216,0.218 ; 0.210,0.214,0.216,0.220)$ \\
\hline $\mathbf{4}$ & $(0.217,0.219,0.221,0.223 ; 0.215,0.219,0.221,0.225)$ \\
\hline $\mathbf{5}$ & $(0.222,0.224,0.226,0.228 ; 0.220,0.224,0.226,0.230)$ \\
\hline $\mathbf{6}$ & $(0.2235,0.2255,0.2275,0.2295 ; 0.2215,0.2255,0.2275$, \\
& $0.2315)$ \\
\hline $\mathbf{7}$ & $(0.225,0.227,0.229,0.231 ; 0.223,0.227,0.229,0.233)$ \\
\hline $\mathbf{8}$ & $(0.2265,0.2285,0.2305,0.2325 ; 0.2245,0.2285,0.2305$, \\
\hline $\mathbf{9}$ & $(0.228,0.230,0.232,0.234 ; 0.226,0.230,0.232,0.236)$ \\
\hline $\mathbf{1 0}$ & $(0.2295,0.2315,0.2335,0.2355 ; 0.2275,0.2315,0.2335$, \\
& $0.2375)$ \\
\hline $\mathbf{1 1}$ & $(0.231,0.233,0.235,0.237 ; 0.229,0.233,0.235,0.239)$ \\
\hline $\mathbf{1 2}$ & $(0.2325,0.2345,0.2365,0.2385 ; 0.2305,0.2345,0.2365$, \\
& $0.2315)$ \\
\hline $\mathbf{1 3}$ & $(0.234,0.236,0.238,0.240 ; 0.232,0.236,0.238,0.242)$ \\
\hline $\mathbf{1 4}$ & $(0.2355,0.2375,0.2395,0.2415 ; 0.2335,0.2375,0.2395$, \\
& $0.2435)$ \\
\hline $\mathbf{1 5}$ & $(0.237,0.239,0.241,0.243 ; 0.235,0.239,0.241,0.245)$ \\
\hline
\end{tabular}

In addition, it is assumed that productivity loss of $1.0 \%$ per year for the investment life of 20 years in any investment year.

\section{Capital Budgeting of Investment Cost and Weighted Average Cost of Capital}

While $30 \%$ of the capital budget of the solar energy investment is covered by the shareholders, the other $70 \%$ is covered by the bank credit. $\left(\mathrm{i}=\% 6.5, \mathrm{k}_{\mathrm{d}}=15 \%\right.$, Tax rate $=\% 20$ )

$$
\mathrm{WACC}=\% 6.50 * 0.70 * 0.80+\% 15.00 * 0.30=\% 8.10
$$

\section{Volatility (Standard Deviation)}

The value calculated with the historical volatility calculation for the model is also used for comparison and the electricity prices become the basis for this calculation. 98 monthly electricity price data have been taken since July 2009 from Exist (Energy Exchange Istanbul) are calculated for historical volatility. While the monthly volatility value is $15.20 \%$, the annual value is $52.85 \%$. The value is different each year because cash flows are used both in the risk-seeker and the risk-averse models in the volatility calculation made with the variance of the intuitionistic trapezoidal number. The volatility values used for each year are indicated below:
Volatility (Standard Deviation)

\begin{tabular}{|c|c|c|}
\hline Year & Risk Seeking & Risk Averse \\
\hline $\mathbf{1}$ & 0.495 & 0.422 \\
\hline $\mathbf{2}$ & 0.410 & 0.348 \\
\hline $\mathbf{3}$ & 0.417 & 0.353 \\
\hline $\mathbf{4}$ & 0.629 & 0.529 \\
\hline $\mathbf{5}$ & 0.637 & 0.536 \\
\hline $\mathbf{6}$ & 0.677 & 0.570 \\
\hline $\mathbf{7}$ & 0.721 & 0.606 \\
\hline $\mathbf{8}$ & 0.770 & 0.646 \\
\hline $\mathbf{9}$ & 0.825 & 0.691 \\
\hline $\mathbf{1 0}$ & 0.889 & 0.743 \\
\hline $\mathbf{1 1}$ & 0.965 & 0.804 \\
\hline $\mathbf{1 2}$ & 1.063 & 0.881 \\
\hline $\mathbf{1 3}$ & 1.191 & 0.981 \\
\hline $\mathbf{1 4}$ & 1.363 & 1.112 \\
\hline $\mathbf{1 5}$ & 1.602 & 1.290 \\
\hline
\end{tabular}

Annual Business Expenses, Tax Rate, Risk-Free Interest Rate, Amortization Method, Investment Life

The annual cost of 300000 Euros is taken as the annual business expenses. The business expense is also considered 200000 Euros in the first year which is the year of plant installation without production. Tax rate $=\% 20$, Risk-Free Interest Rate $=\% 4.50$. Useful life is 10 year for solar energy investment. So, normal amortization (\%10) is applied to our investment project. Investment life is 20 year.

\section{Results of the Research}

In the study, first, the net present value is evaluated in order to answer to the question if the investment is done today, whether it can be done profitably or not. The net present value of the solar energy investment project which generates energy from photovoltaic cells, is calculated as ($8167423,-6784107,-5333159,-3807334$; -8584591, 6784107, -5333159, -1263337) Euros intuitionistic fuzzy number. It does not seem to be done for today with the expected value of -5757152 Euro. With the share of deferment (postponement) flexibility provided by the real option valuation, it will be questioned whether the project will be profitable in the years to come, and if so, in which year it will be the most profitable. In this case the extended net present value will be used as a criterion. The expected values of the results of study below indicate the given critical value.

For the 15 different investment years in the table below (table 8), real option valuation is observed within the assumptions and the expected extended net present values as well as the expected net present value and expected option values are obtained. The following results are obtained according to the data of the modeling:

- We reached the positive expected expanded net present value by the investment carried out after 4 years thanks to the model in which the standard deviation found with HV (historical volatility) calculation. This is the first profitable year according to our basic criterion. On the other hand, in this model, with a 6-year delay, both the expected option value and the expected extended net present value reach the maximum.

- The expected net present value of the project is positive for the first time due to the investment postponed for 5 years. In addition, the $7^{\text {th }}$ year reaches its maximum. 
However, these situations do not include standard deviation, which is the expression of uncertainty created by various ambiguous situations. Uncertainty has thus not yet fully modeled.

- For the first time in the RA (risk averse) model, the expected expanded net present value reaches the present value due to the investment postponed for 4 years. Thanks to this model, the investment to be performed in the $10^{\text {th }}$ year reaches its maximum expected option value and in the $9^{\text {th }}$ year reaches its maximum expected expanded net present value. Regarding to our main criteria, the project should be realized with this modeling after postponing for 9 years.

- For the first time in RS (risk seeker) model, the investment to be performed after 4 year postponement reaches the expanded net present value. Thanks to this model, it reaches its maximum expected expanded net present value in the investment with 8 year delay while reaching its maximum expected option value with the investment to be carried out in 9th year. Regarding to our main criteria, the project should be realized with this modeling after postponing for 8 years. Moreover, when other valuations are considered, this expected net extended present value provides the highest profitability of the project.

- Thus, models with frequency-standard deviations modeled this phenomenon due to the increasing uncertainty of intuitionistic fuzzy numbers over the years and increased the risk perception. The historical volatility model has remained constant throughout the model, resulting in a more conservative structure. On the other hand, it is observed that there is a difference between the frequency models in terms of the value of the investment and the difference in the optimum year in which the investment should be realized is very small. So, there is no difference in terms of optimum investment year between frequency models. But, optimum investment year in HV model shows its difference with its early investment realization.

Table 8

Expected Value of Decision Criteria(Euros)

\begin{tabular}{|c|c|c|c|c|c|c|c|c|}
\hline $\mathbf{T}$ & ${ }^{*} \mathbf{N P V}\left({ }_{\mathbf{R S}}\right)$ & NPV $\left(\mathbf{L}_{\mathbf{R A}}\right)$ & $\begin{array}{c}\text { OPTION } \\
\text { VALUE }(\mathbf{R S})\end{array}$ & $\begin{array}{c}\text { OPTION } \\
\text { VALUE }\left({ }^{\ddagger} \mathbf{H V}\right)\end{array}$ & $\begin{array}{c}\text { OPTION } \\
\text { VALUE (RA) }\end{array}$ & ${ }^{+}$ENPV (RS) & ENPV (HV) & ENPV (RA) \\
\hline $\mathbf{1}$ & -4254266 & -4348487 & 177677 & 215402 & 81234 & -4076589 & -4038865 & -4267253 \\
\hline $\mathbf{2}$ & -2495864 & -2579721 & 593092 & 918924 & 373451 & -1902772 & -1576940 & -2206270 \\
\hline $\mathbf{3}$ & -1488556 & -1565570 & 1086179 & 1469961 & 790270 & -402378 & -18595 & -775299 \\
\hline $\mathbf{4}$ & -396678 & -414772 & 1863884 & 1597786 & 1518767 & $\mathbf{1 4 6 7 2 0 6}$ & $\mathbf{1 2 0 1 1 0 8}$ & $\mathbf{1 1 0 3 9 9 5}$ \\
\hline $\mathbf{5}$ & $\mathbf{1 0 9 5 4 6}$ & $\mathbf{9 2 8 6 4}$ & 2200920 & 1902824 & 1846360 & 2310467 & 2012370 & 1939224 \\
\hline $\mathbf{6}$ & 132991 & 121705 & 2330272 & $\mathbf{1 9 2 4 8 6 1}$ & 1967177 & 2463263 & $\mathbf{2 0 5 7 8 5 2}$ & 2088882 \\
\hline $\mathbf{7}$ & $\mathbf{1 3 3 7 0 2}$ & $\mathbf{1 2 8 8 8 9}$ & 2421057 & 1918846 & 2059704 & 2554759 & 2052548 & 2188592 \\
\hline $\mathbf{8}$ & 113585 & 116407 & 2477563 & 1891209 & 2127829 & $\mathbf{2 5 9 1 1 4 8}$ & 2004794 & 2244236 \\
\hline $\mathbf{9}$ & 74261 & 85981 & $\mathbf{2 5 0 2 2 9 9}$ & 1846688 & 2174055 & 2576560 & 1920949 & $\mathbf{2 2 6 0 0 3 6}$ \\
\hline $\mathbf{1 0}$ & 17086 & 39087 & 2498797 & 1788890 & $\mathbf{2 1 9 9 5 1 0}$ & 2515883 & 1805977 & 2238597 \\
\hline $\mathbf{1 1}$ & -123328 & -90094 & 2431444 & 1679430 & 2163277 & 2308117 & 1556102 & 2073183 \\
\hline $\mathbf{1 2}$ & -271379 & -225242 & 2342907 & 1567193 & 2112505 & 2071528 & 1295814 & 1887263 \\
\hline $\mathbf{1 3}$ & -427351 & -366449 & 2227868 & 1453132 & 2040039 & 1800517 & 1025781 & 1673590 \\
\hline $\mathbf{1 4}$ & -591999 & -514141 & 2084310 & 1337788 & 1937924 & 1492310 & 745788 & 1423783 \\
\hline $\mathbf{1 5}$ & -765704 & -668510 & 1918158 & 1221331 & 1801272 & 1152454 & 455627 & 1132762 \\
\hline
\end{tabular}

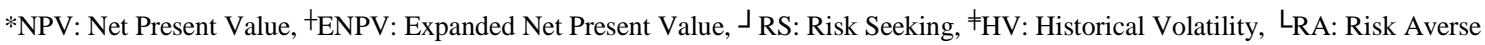

\section{Conclusion}

Real options have been the subject of many studies in the field of investment analysis. The concepts of uncertainty and managerial flexibility, which are not included in the classical methods used in project evaluation, can be modeled by this method. Subsequently, Carlsson and Fuller proposed a fuzzy real-option model because these numbers can be used as fuzzy numbers for situations where investment costs and cash flows cannot be modeled as a single number. In this study, since the uncertainty of cash flows and investment costs can be modeled in a wider context, cash flow and investment cost are expressed as intuitionistic fuzzy numbers and an intuitionistic fuzzy real-option model is proposed. Moreover, the variables that determine cash flows and costs are expressed as intuitionistic fuzzy numbers. In addition, when multiple decision makers are needed, the intuitionistic fuzzy numbers that the decision makers provide for the variables can be transferred to the model with aggregation methods. Thus, when deciding in a market with intense uncertainty, we propose a model in which multiple decision makers are involved, including the hesitation degree. Owing to this model, decision makers are able to determine their hesitation effectively. Moreover, this generalization provides the model that involves further information and the transfer of information to the last stage of the model.

This study examines whether a licensed project based on a photovoltaic solar panel system in Turkey can be profitably realized and when this investment should be performed based on the proposed model. Uncertainty is modeled in a wide scope using many variables as an intuitionistic trapezoidal fuzzy number. In addition, uncertainty expression, which is a variable in the model, is calculated both through risk perception and historical volatility on expected values. Regarding the observation, a minimal difference is observed between the models calculated on expected values according to various risk perceptions. On the other hand, a significant difference is 
observed between the fixed standard deviation, historical volatility, and other factors. The uncertainty rising over the years in the model calculated from the expected values increases the value of the standard deviation. This condition allows the decision maker to make flexible decisions.

As a result, the investment project, which cannot be realized under the current conditions, will be profitable in the future with the option of postponement brought by managerial flexibility in the real-options theory. The most profitable year depends on the standard deviation used for uncertainty. In this manner, decision makers can choose what expression to use for uncertainty based on current market conditions.

\section{References}

Agliardi, E., \& Agliardi, R. (2003). A generalization of the Geske formula for compound options. Elsevier Mathematical Social Sciences, 45, 75-82. https://doi.org/10.1016/S0165-4896(02)00081-1

Amram, M., \& Kulatilaka, N. (1999). Real Options: Managing Strategic Investment in an Uncertain World. Boston: Harvard Business School Press.

Aranda, F., C., Arango, F., O., \& Lianos, A., I., C. (2016). Project Valuation of a Distribution Centre of an Auxiliary Rail Freight Terminal: Using Real Options with Fuzzy Logic and Binomial Trees. Journal of Applied Economic Sciences, 11(5), 894-904.

Atanassov, K. T. (1983). Intuitionistic fuzzy sets, VII ITKR's Session, Sofia (deposed in Central Science-Technical Library of Bulgarian Academy of Science, 1697/84).

Biancardi, M., \& Villani, G. (2017). A fuzzy approach for R\&D compound option valuation. Fuzzy Sets and Systems, 310, 108-121. https://doi.org/10.1016/j.fss.2016.10.013

Black, F., \& Scholes, M. (1973). The pricing of options and corporate liabilities. Journal of Political Economy, 81(3), 637-654. Available from Internet: https://www.jstor.org/stable/1831029 . https://doi.org/10.1086/260062

Carlsson, C., \& Fuller, R. (2001). On possibilistic mean value and variance of fuzzy numbers. Fuzzy Sets and Systems, 122(2), 315-326. https://doi.org/10.1016/S0165-0114(00)00043-9

Carlsson, C., \& Fuller, R. (2003). A fuzzy approach to real option valuation. Fuzzy Sets and Systems, 139(2), $297-312$. https://doi.org/10.1016/S0165-0114(02)00591-2

Copeland, T., \& Antikarov, V. (2001). Real options: A practitioner's guide. New York, NY: Texere Publishing Limited.

Dai, H., Sun, T., \& Guo, W. (2016). Brownfield Redevelopment Evaluation Based on Fuzzy Real Options. Sustainability, 8(2), 170. https://doi.org/10.3390/su8020170

Dixit, A. K., \& Pindyck, R. S. (1995). The option approach to capital investment. Harvard Business Review, 73(3), 105115. Available from Internet: https://hbr.org/1995/05/the-options-approach-to-capital-investment

Garibaldi, J. M., Musikasuwan, S., \& Ozen, T. (2005). The association between non-stationary fuzzy sets and interval type-2 fuzzy sets: A case study, submitted to IEEE International Conference on Fuzzy Systems, $224-229$. https://doi.org/10.1109/FUZZY.2005.1452397

Geske, R. (1979). The valuation of compound options. Journal of Financial Economics, 7, 63-81. Available from Internet: http://citeseerx.ist.psu.edu/viewdoc/download?doi=10.1.1.453.2801\&rep=rep1\&type=pdf. https://doi.org/10.1016/0304-405X(79)90022-9

Grzegrorzewski, P. (2003). Intuitionistic fuzzy numbers. In Proceedings of the 10th IFSA world congress. Istanbul, Turkey, 35-38.

Heng, A., Chen, Q., \& Tan, Y. (2014). Fuzzy Optimization of Option Pricing Model and Its Application in Land Expropriation. Journal of Applied Mathematics. http://dx.doi.org/10.1155/2014/635898

Ho, S. H., \& Liao, S. H. (2011). A fuzzy real option approach for investment project valuation. Expert Systems with Applications, 38(12), 15296-15302. https://doi.org/10.1016/j.eswa.2011.06.010

Kozlova, M., Collan, M., \& Luukka, P. (2016). Comparison of the Datar-Mathews Method and the Fuzzy Pay-Off Method through Numerical Results. Advances in Decision Sciences. https://doi.org/10.1155/2016/7836784

Kumar, M. (2014). Applying weakest t-norm based approximate intuitionistic fuzzy arithmetic operations on different types of intuitionistic fuzzy numbers to evaluate reliability of PCBA fault. Applied Soft Computing, 23, $387-406$. https://doi.org/10.1016/j.asoc.2014.06.036

Lee, Y. C., \& Lee, S. S. (2011). The valuation of RFID investment using fuzzy real option. Expert Systems with Applications, 38(10), 12195-12201. https://doi.org/10.1016/j.eswa.2011.03.076 
Luehrman, T. A. (1998). Investment opportunities as real options: Getting started on the numbers. Harvard Business Review, 76(6), 51-67. Available from Internet: http://id.lib.harvard.edu/aleph/000132706/catalog

Merton, R. C. (1973). Theory of Rational Option Pricing. Bell Journal of Economics and Management Science, 4(1), 141183. https://doi.org/10.2307/3003143

Myers, S., C. (1977). Determinant of corporate borrowing. Journal of Financial Economies, 5(2), $147-175$. https://doi.org/10.1016/0304-405X(77)90015-0

Nagoorgani, A., \& Ponnalagu, K. (2012). A New Approach on Solving Intuitionistic Fuzzy Linear Programming Problem. Applied Mathematical Sciences, 70(6), 3467-3474.

Nehi, H. M., \& Maleki, H. R. (2005). Intuitionistic fuzzy numbers and it's applications in fuzzy optimization problem. In Proceedings of the 9th WSEAS international conference on systems, Athens, Greece, 1-5. Available from Internet: http://www.wseas.us/e-library/conferences/2005athens/cscc/papers/497-721.pdf

Shabani, A., \& Jamkhaneh, E., B. (2014). A New Generalized Intuitionistic Fuzzy Number. Journal of Fuzzy Set Valued Analysis, 1-10. Available from Internet: http://www.ispacs.com/journals/jfsva/2014/jfsva-00199/article.pdf . https://doi.org/10.5899/2014/jfsva-00199

Shaw, A. K., \& Roy, T. K. (2012). Some arithmetic operations on Triangular Intuitionistic Fuzzy Number and its application on reliability evaluation. International Journal of Fuzzy Mathematics and Systems, 2(4), $363-382$. Available from Internet: https://www.ripublication.com/ijfms/ijfmsv2n4_02.pdf

Smarandache, F. (1999). A unifying field in logics. neutrosophy: Neutrosophic probability, set and logic, American Research Press, Rehoboth.

Tolga, C. (2009). Fuzzy Real Option Approach to the Evaluation of Research and Development Projects, PhD Thesis, Istanbul Technical University.

Tolga, C., Kahraman, C., \& Demircan, M. L. (2010). A Comperative Fuzzy Real Options Valuation Model using Trinomial Lattice and Black-Scholes Approaches: A Call Center Application. Journal of Multiple Valued Logic and Soft Computing, 16(1/2), 135-154. Available from Internet: www.oldcitypublishing.com/FullText/...1.../MVL SCv16n1-2p135-154Tolga.pdf

Torra, V. (2010). Hesitant fuzzy sets. International Journal of Intelligent Systems, 25(6), 529-539. https://doi.org/10.1002/int.20418

Trigeorgis, L. (1993). Real options and interactions with financial flexibility. Financial Management, 22(3), $202-224$. https://doi.org/10.2307/3665939.

Trigeorgis, L. (1996). Real options: Managerial Flexibility and Strategy in Resource Allocation, Resources Policy, 22(3), 218-220. https://doi.org/10.1016/S0301-4207(97)84900-8

Ucal, I., \& Kahraman, C. (2009). Fuzzy real options valuation for oil investments. Technological and Economic Development of Economy, 15(4), 646-669. http://dx.doi.org/10.3846/1392-8619.2009.15.646-669

Yager, R. R. (1986). On the Theory of Bags. International Journal of General Systems, 13(1), 23-37. https:// doi.org/10.1080/03081078608934952

You, C. J., Lee, C. K. M., Chen, S. L., \& Jiao, R. J. (2012). A real option theoretic fuzzy evaluation model for enterprise resource planning investment. Journal of Engineering and Technology Management, 29(1), 47-61. https://doi.org/10.1016/j.jengtecman.2011.09.005

Zadeh, L. A. (1965). Fuzzy sets. Information and Control, 8(3), 338-353. https://doi.org/10.1016/S0019-9958(65)90241-X

Zadeh, L. A. (1975). The concept of a linguistic variable and its application to approximate reasoning - 1. Information Sciences, 8(3), 199-249. https://doi.org/10.1016/0020-0255(75)90036-5

Zainali, Z., Akbari, M. G., \& Noughabi, H. A. (2015). Intuitionistic fuzzy random variable and testing hypothesis about its variance. Soft Computing, 19(9), 2681-2689. https://doi.org/10.1007/s00500-014-1437-z

Zmeskal, Z. (2010). Generalized soft binomial American real option pricing model (fuzzy-stochastic approach). European Journal of Operational Research, 207(2), 1096-1103. https://doi.org/10.1016/j.ejor.2010.05.045

The article has been reviewed.

Received in October, 2017; accepted in April, 2018. 